\title{
Phytoplankton Community as A Bioindicator for Water Quality of Sumi Dam, Bima Regency
}

\author{
Muhamad Hairil Anas ${ }^{1}$, Lalu Japa ${ }^{1^{*}}$, Khairuddin ${ }^{1}$ \\ ${ }^{1}$ Biology Education Study Program, Teacher Training and Education Faculty, University of \\ Mataram, Indonesia
}

\author{
Article History \\ Received : December $11^{\text {th }}, 2021$ \\ Revised : December $29^{\text {th }}, 2021$ \\ Accepted : January $15^{\text {th }}, 2022$ \\ Published : January $24^{\text {th }}, 2022$ \\ *Corresponding Author: \\ Lalu Japa, \\ Biology Education Study \\ Program, Teacher Training and \\ Education Faculty, University of \\ Mataram, Indonesia; \\ Email: ljapa@unram.ac.id
}

\begin{abstract}
The waters of the Sumi dam have an important role in accordance with the purpose of its construction. Therefore, monitoring of water quality becomes necessary because good water quality is an important requirement for every organism. This study aims to examine the water quality of the Sumi dam based on the community and species diversity of phytoplankton. The sampling location was determined based on the purposive sampling method. Water samples were taken in April 2021 using a 20 micron plankton net and preserved with formalin at a concentration of $4 \%$ preservation. The results showed that the identified phytoplankton community in the Sumi Dam consisted of 80 species and 13 classes. The index value of the diversity of phytoplankton species in the Sumi dam is high. Based on the index value of the diversity of phytoplankton species as a bioindicator, the waters of the Sumi dam are included in the unpolluted category.
\end{abstract}

Keywords: Bioindikator; Phytoplankton; Sumi Dam; Water Quality

\section{Pendahuluan}

Fitoplankton merupakan salah satu organisme akuatik yang dapat digunakan sebagai parameter lingkungan (Bioindikator) untuk menentuhkan kondisi suatu perairan (Zohri et al. 2020). Selanjutnya Japa dan Khairuddin, (2014) menyatakan, bahwa fitoplankton ialah organisme perairan yang banyak digunakan dalam menentukan kualitas serta produktivitas suatu perairan. Fitoplankton dapat dijadikan sebagai indikator kualitas perairan karena mempunyai toleransi spesifik pada lingkungan, dan tersebar diseluruh massa perairan (Apridayanti, 2008). Sifat yang dimiliki oleh fitoplankton sesuai dengan kriteria organisme yang terseleksi untuk menjadi monitor biologi yaitu: (1) Memiliki sifat yang peka terhadap perubahan kondisi lingkungan, (2) Penyebaranya luas, (3) mudah diperoleh dalam jumlah yang melimpah, serta (4) Mempunyai kedudukan dalam ekologi, ekonomi maupun rekreasi, (Mason, 1991 dalam Khairuddin, et al., 2016).

Parameter fisika, kimia dan biologi merupakan parameter lingkungan yang dapat digunakan untuk mengevaluasi kualitas suatu perairan. Namun, penentuan kualitas air menggunakan parameter fisika maupun kimia sangat membutuhkan waktu serta biaya yang banyak (Khairuddin, et al., 2016). Oleh karena itu, penentuan kualitas air secara biologi menjadi pilihan yang tepat. Penentuan kualitas air secara biologi biasanya menggunakan keberadaan populasi organisme akuatik sebagai acuan dalam menentuhkan kualitas perairan. Salah satu organisme air yang digunakan untuk menentukan kondisi suatu perairan adalah fitoplankton. Fitoplankton dapat ditemukan di semua perairan termasuk perairan bendungan (Heriyanto, 2016).

Indonesia mempunyai lebih dari 200 Bendungan yang tersebar diseluruh wilayah dan 72 diantaranya tersebar di wilayah Provinsi Nusa Tenggara Barat (Kementerian Pekerjaan Umum dan Perumahan Rakyat, 2021). Salah satu bendungan yang ada di Nusa Tenggara Barat adalah bendungan Sumi. Bendungan Sumi terletak di Desa Mangge, Kecamatan Lambu, Kabupaten Bima memiliki berbagai peranan sesuai tujuan pembangunannya. Adapun tujuan pembangunan bendungan Sumi antara lain adalah: (1) untuk mengairi daerah irigasi dengan jumlah areal 2.272 ha, (2) menunjang swasembada pangan (3) menunjang komoditi andalan lainnya seperti peningkatan produksi peternakan, perikanan air tawar dan pariwisata di Kabupaten Bima serta (4) menyediakan kebutuhan air bersih untuk Kecamatan Sape dan Lambu sebesar 50 liter/detik (Direktorat Jenderal Sumber Daya Air Nusa Tenggara Barat, 2021). 
Tujuan pembangunan bendungan Sumi ini tentunya akan tercapai apabila air bendungan memenuhi persyaratan fisika, kimia maupun persyaratan biologi air yang memiliki kualitas baik. Persyaratan fisika air yang berkualitas baik yaitu: (1) mempunyai kondisi yang jernih, (2) Tidak berwarna, (3) memiliki rasa yang tawar, (4) Tidak memiliki bau, (5) mempunyai suhu yang normal, dan (6) Tidak terdapat zat padatan. Sedangkan persyaratan kimia air yang berkualitas baik yaitu: (1) memiliki derajat keasaman (pH) yang normal, (2) Tidak mengandung zat-zat kimia beracun, (3) Tidak memuat ion-ion logam, (4) memiliki kesadahan yang rendah, serta (5) Tidak terdapat berbagai bahan organik. Persyaratan biologi kualitas air yang tergolong baik yaitu tidak mengandung organisme patogen (PERMENKES No. 492, 2010). Pemantauan kualitas air menggunakan komunitas fitoplankton sebagai bioindikator sejatinya telah banyak dilaporkan. Salah satunya penelitian Aryawati et al. (2021) yang memperlihatkan perairan sungai Musi bagian hilir terkategori dalam kondisi tercemar sedang hingga berat.

Pemantauan kualitas air menggunakan fitoplankton sebagai bioindikator dapat memberi informasi tentang status kualitas perairan yang akan memberikan pengaruh terhadap berbagai penanganan yang bisa diambil dalam mengevaluasi kualitas air (Prilestari et al., 2019). Selanjutnya, nilai indeks keanekragaman spesies fitoplankton akan memperlihatkan tingkat pencemaran suatu perairan (Zohri et al., 2020). Khalis (2021) menyatakan bahwa menggunakan komunitas fitoplankton untuk memantau kualitas air akan memaparkan informasi yang lebih banyak terkait perubahan kualitas air dibandingkan menggunakan konsentrasi klorofila sebagai acuan penentuan kualitas air.

Menyadari bahwa sampai saat ini,
informasi mengenai keanekaragaman fitoplankton yang digunakan sebagai bioindikator kualitas perairan di Bendungan Sumi Kabupaten Bima belum dilakukan, maka perlu dilakukan penelitian yang bertujuan untuk memaparkan kondisi perairan bendungan Sumi menggunakan bioindikator fitoplankton. Informasi dari studi ini diharapkan akan memaparkan kondisi atau kualitas air bendungan Sumi secara umum sehingga bisa dilakukan kajian tentang pengelolaan dan pemanfaatan perairan bendungan, baik oleh masyarakat sekitar, lembaga pemerintah maupun instasi terkait.

\section{Bahan dan Metode}

\section{Tempat dan Waktu}

Sampel penelitian deskriptif eskploratif ini diambil di Bendungan Sumi pada bulan April 2021. Pengamatan dan identifikasi sampel fitoplankton dilakukan di Laboratorium Biologi Fakultas Keguruan dan Ilmu Pendidikan Universitas Mataram.

\section{Populasi dan Sampel}

Populasi penelitian ini yaitu fitoplankton yang terdapat di Bendungan Sumi. Sedangkan sampel penelitian adalah fitoplankton yang tersaring jaring plankton ukuran $20 \mu \mathrm{m}$ pada titik pengambilan sampel. Tiga titik pengambilan sampel (dua pada bagian inlet dan satu pada bagian outlet) bendungan (Gambar 1) ditentukan secara Purposive sampling method.

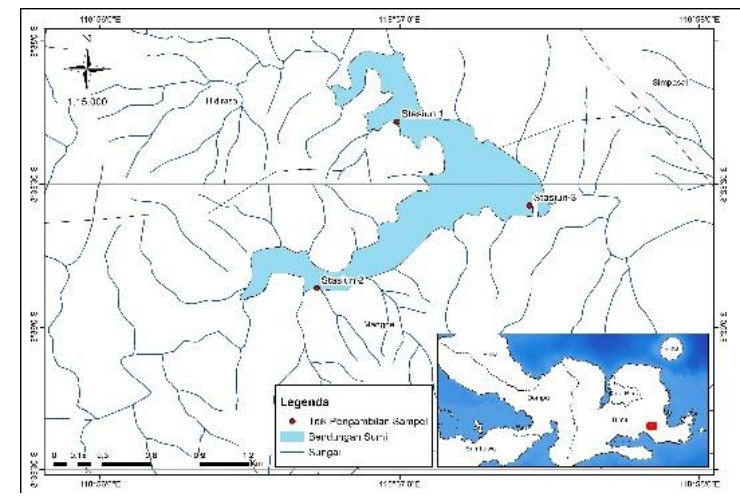

Gambar 1. Sebaran Titik Pengambilan Sampel di Bendungan Sumi

\section{Pengambilan Sampel}

Sampel fitoplankton diambil dengan menyaring air di bagian permukaan setiap titik sampel sebanyak 100 liter menggunakan jaring plankton dengan ukuran $20 \mu \mathrm{m}$. Sampel diawetkan menggunakan formalin pada konsentrasi pengawetan $4 \%$. Identifikasi spesies fitoplankton berdasarkan ukuran, bentuk, dan bentuk koloni (Zohri et al., 2020), dengan mengacu pada buku identifikasi: Wehr dan Sheath (2003), Vuuren et al. (2006), Suthers dan Rissik (2009), Bellinger dan Sigee (2010), McLaughlin (2012), dan Sahoo dan Seckbach (2016).

\section{Analisis Data}

Spesies fitoplankton yang teridentifikasi, kemudian dihitung kelimpahan dan indeks keanekaragaman spesiesnya. Keanekaragaman spesies fitoplankton dianalisis berdasarkan 
indeks keanekaragaman Shanon-winer yang tercantum dalam Barus (2002) adalah sebagai berikut:

$$
\mathrm{H}^{\prime}=-\sum \mathrm{Pi} \ln \mathrm{Pi}
$$

Keterangan:

$\mathrm{H}^{\prime} \quad$ : Indeks keanekaragaman Shanon-
Pi : Peluang kepentingan untuk tiap spesies (ni/N)

$\mathrm{Ni}$ : Jumlah individu spesies ke-i

$\mathrm{N} \quad$ : Jumlah total individu seluruh spesies

Tingkat pencemaran menurut Husamah dan Rahardjanto (2019) berdasarkan nilai indeks keanekaragaman spesies fitoplankton dapat dilihat pada Tabel 1.

Tabel 1. Kriteria Pencemaran Air Berdasarkan Indeks Keanekaragaman spesies fitoplankton

\begin{tabular}{llll}
\hline No. & $\begin{array}{l}\text { Nilai } \\
\text { Keanekaragaman }\end{array}$ & $\begin{array}{l}\text { Kategori } \\
\text { keanekaragaman }\end{array}$ & Tingkat Pencemaran \\
\hline 1. & $\mathrm{H}^{\prime} \leq 1,0$ & Rendah & Tercemar Berat \\
2. & $\mathrm{H}^{\prime}>1,0-<3,0$ & Sedang & Tercemar sedang \\
3. & $\mathrm{H}^{\prime} \geq 3,0$ & Tinggi & Tidak Tercemar \\
\hline
\end{tabular}

Penghitungan kelimpahan fitoplankton

menggunakan rumus (Ariana et al., 2014):

$$
\mathrm{N}=\mathrm{Z} \times \frac{X}{Y} \times \frac{1}{V}
$$

Keterangan:

$\mathrm{N}$ : Kelimpahan individu fitoplankton

(individu/liter)

$\mathrm{Z}$ : Jumlah individu fitoplankton

$\mathrm{X} \quad$ : Volume air sampel yang tersaring $(\mathrm{ml})$

Y : Volume 1 tetes air (ml)

$\mathrm{V} \quad$ : Volume air yang disaring (L)

Selanjutnya Landner (1978) dalam

Suryanto dan Umi (2009) kesuburan perairan berdasarkan kelimpahan fitoplankton dibagi

menjadi:

Oligotrofik (Kurang subur) $\quad: 0-2000$

ind $/ \mathrm{ml}$

Mesotrofik (Kesuburan sedang) : 2000 - 15000

ind $/ \mathrm{ml}$

Eutrofik (Sangat subur) $\quad:>15000 \mathrm{ind} / \mathrm{ml}$

\section{Hasil dan Pembahasan}

\section{Komposisi Fitoplankton}

Komunitas fitoplankton yang teridentifikasi di perairan bendungan Sumi terdiri dari 80 spesies dan 13 kelas. Perbandingan jumlah spesies setiap kelas fitoplankton (Tabel 2).

Tabel 2. Perbandingan Jumlah Spesies Setiap Kelas Fitoplankton di Bendungan Sumi

\begin{tabular}{clcc}
\hline No. & \multicolumn{1}{c}{ Kelas } & $\begin{array}{c}\text { Jumlah } \\
\text { Spesies }\end{array}$ & $\begin{array}{c}\text { Persentase setiap kelas } \\
\text { fitoplangkton }(\%)\end{array}$ \\
\hline 1. & Bacillariophyceae & 20 & 25,00 \\
2. & Chlorophyceae & 15 & 18,75 \\
3. & Cyanophyceae & 8 & 10,00 \\
4. & Euglenophyceae & 8 & 10,00 \\
5. & Trebouxiophyceae & 6 & 7,50 \\
6 & Zygnematophyceae & 6 & 7,50 \\
7. & Mediophyceae & 5 & 6,25 \\
8 & Dinophyceae & 4 & 5,00 \\
9 & Coscinodiscophyceae & 3 & 3,75 \\
10. & Eustigmatophyceae & 2 & 2,50 \\
11. & Hormogoneae & 1 & 1,25 \\
12. & Stylonematophyceae & 1 & 1,25 \\
13. & Xanthophyceae & 1 & 1,25 \\
& Total & 80 & 100,00 \\
\hline
\end{tabular}

Sumber:Dokumentasi pribadi (2021) 
Spesies fitoplankton yang paling banyak ditemukan adalah dari kelas Bacillariophyceae. Spesies fitoplankton dari kelas Bacillariophyceae memiliki kemampuan beradaptasi yang tinggi dengan lingkungan, distribusinya yang luas, reproduksi yang cepat dan bisa ditemukan di hampir semua substrat (Komalasari, et al., 2020; Odum, 1998). Rumanti et al. (2014) mempertegas bahwa spesies fitoplankton dari kelas Bacillariaphyceae memiliki kemampuan reproduksi yang cepat dan mampu menyesuaiakan diri dengan baik terhadap berbagai perubahan lingkungan serta memiliki kemampuan yang baik dalam memanfaatkan unsur hara dibandingkan spesies fitoplankton dari kelas lain. Dalam kondisi unsur hara yang sama, spesies fitoplankton dari kelas Bacillariophyceae mampu bereproduksi sebanyak tiga kali dalam kurun waktu 24 jam, sedangkan spesies fitoplankton dari kelas Dinophyceae hanya mampu bereproduksi satu kali dalam kurun waktu yang sama. (Praseno dan Sugestiningsih, 2000).

\section{Kelimpahan Fitoplankton}

Kelimpahan fitoplankton di perairan bendungan Sumi bervariasi dari stasiun satu ke stasiun lainnya. Perbandingan data kelimpahan setiap stasiun dapat dilihat pada Gambar 2.

\section{Kelimpahan (Sel/L}

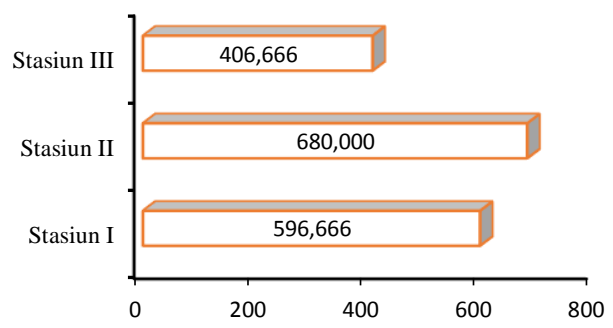

Gambar 2. Diagram Perbandingan Nilai Kelimpahan Fitoplankton Pada Masing-Masing Stasiun Perairan Bendungan Sumi

Kelimpahan tertinggi tercatat pada stasiun II yaitu 680,000 sel/L. Kemudian disusul dengan stasiun I yaitu 596,666 sel/L. Sedangkan kelimpahan terendah $(406,666 \mathrm{sel} / \mathrm{L})$ terdapat pada stasiun III. Suryanto dan Umi (2009) memaparkan bahwa perairan dengan kelimpahan fitoplankton yang berkisar antara 0-2000 individu/ml tergolong dalam perairan oligotrofik. Perairan oligotrofik memiliki fisik yang jernih serta kelimpahan tanaman air serta alga yang kurang dibandingkan perairan mesotrofik maupun perairan eutrofik (Zulfiah dan Aisyah, 2016).

Tingginya kelimpahan fitoplankton pada stasiun II bisa jadi disebabkan oleh karena kawasan ini merupakan inlet bendungan Sumi yang menjadi tempat berkumpulnya masukan zat hara yang berasal dari sungai. Stasiun II juga berada di dekat daerah pertanian sehingga nutrisi-nutrisi dari daerah pertanian tersebut akan terbawa air hujan ke dalam bendungan. Kondisi lingkungan (suhu, $\mathrm{pH}$,) perairan di stasiun II juga sangat mendukung untuk pertumbuhan fitoplankton. Selain itu, unsur hara seperti nitrat yang masih dapat mendukung untuk kehidupan fitoplankton juga menjadi salah satu alasan tingginya kelimpahan.

Stasiun I memiliki nilai kelimpahan yang rendah dibandingkan stasiun II. Meskipun letak stasiun I juga berada di inlet bendungan yang merupakan muara sungai dan daerah pertanian, akan tetapi pada saat pengambilan sampel, daerah pertanian di sekitar stasiun I sedang dilakukan penyemprotan insektisida dan pestisida. Faktor inilah yang diduga menjadi salah satu penyebab kelimpahan fitoplankton di stasiun I lebih rendah di bandingkan stasiun II. Sebagaimana pernyataan Taufik (2011) bahwa penimbunan substansi kimia yang terkandung dalam pestisida pada konsentrasi tertentu didalam tubuh organisme secara signifikan dapat menurunkan laju pertumbuhan organisme. Stasiun III yang berada di outlet bendungan memiliki nilai kelimpahan yang paling rendah. Hal ini bisa jadi disebabkan oleh jumlah unsur hara yang cukup rendah, karena unsur hara sudah digunakan dan tersedimentasi di bagian inlet serta di bagaian tengah bendungan. Sebagaimana pernyataan Rahayu (2007) bahwa konsentrasi unsur hara sangat menentuhkan jumlah taksa maupun kelimpahan fitoplankton dalam suatu perairan.

\section{Keanekaragaman Fitoplankton}

Indeks keanekaragaman spesies merupakan indeks yang menyatakan sruktur komunitas dan kestabilan ekosistem. Semakin tinggi indeks keanekaragaman spesies maka suatu ekosistem semakin stabil (Indriyanto, 2012). Nilai keanekaragaman spesies ditentukan dengan banyaknya spesies serta meratanya kelimpahan individu setiap spesies. Perbandingan nilai indeks keanekaragaman spesies setiap stasiun dapat dilihat pada Gambar 3. 


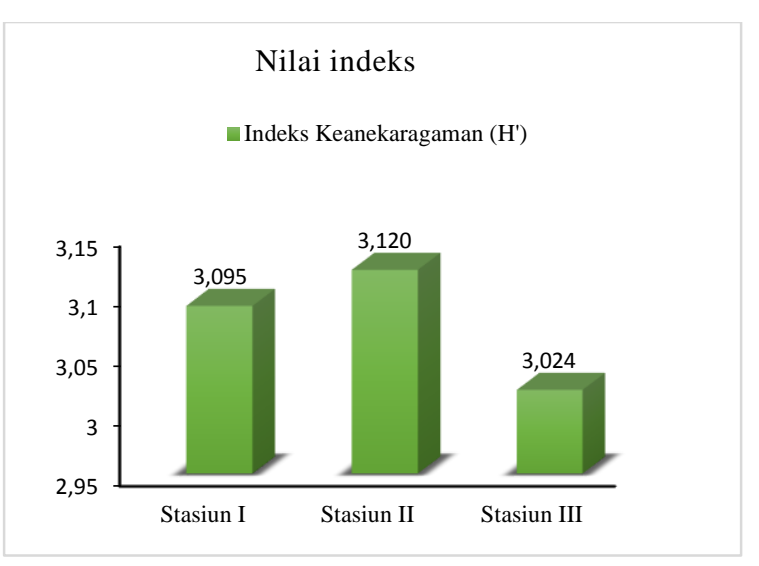

Gambar 3. Diagram Perbandingan Nilai Indeks Keanekaragaman Spesies Fitoplankton Tiap Stasiun di Perairan Bendungan Sumi

Nilai indeks keanekaragaman spesies yang terdapat di bendungan Sumi berkisar antara 3,024-3,120 (termasuk kategori tinggi). Nilai indeks keanekaragaman spesies tertinggi terdapat pada stasiun II yaitu 3,120 dan nilai indeks keanekaragaman spesies untuk stasiun I dan III berturut-turut sebesar 3,095 dan 3,024. Nilai indeks keanekaragaman spesies yang lebih besar dari tiga mengindikasikan keanekaragaman spesies yang tinggi (Husamah dan Rahardjanto, 2019). Tingginya nilai indeks keanekaragaman spesies fitoplankton di perairan bendungan Sumi dipengaruhi oleh faktor fisika-kimia perairan yang masih mampu menompang produktivitas fitoplankton.

\section{Fitoplankton Sebagai Bioindikator Kualitas Perairan}

Air merupakan salah satu kebutuhan dasar dalam kehidupan setiap organisme. Salah satu strategi dalam menentuhkan kualitas air adalah menggunakan komunitas fitoplankton sebagai bioindikator. Nilai keanekaragaman spesies fitoplankton dapat merepresentasikan tingkat pencemaran perairan. Nilai indeks keanekaragaman spesies fitoplankton di perairan bendungan Sumi terkategori tinggi. Nilai indeks keanekaragaman spesies yang tinggi memperlihatkan kemerataan jumlah setiap spesies fitoplankton yang ada di bendungan Sumi relatif sama. Artinya, tidak ada satu spesies fitoplankton yang terlalu tinggi kelimpahannya. Sebagaimana pernyataan Barus (2004) apabila suatu komunitas memiliki jumlah spesies yang banyak dan disertai dengan jumlah individu setiap spesies yang relatif merata, maka komunitas tersebut akan memiliki keanekaragaman spesies yang tinggi. Tingkat pencemaran berdasarkan nilai indeks keanekaragaman spesies fitoplankton Husamah dan Rahardjanto (2019) memperlihatkan perairan bendungan Sumi memiliki kualitas air yang bersih atau tidak tercemar. Kualitas air yang tergolong bersih mengindikasikan perairan bendungan Sumi belum tercemar oleh berbagai kelompok bahan pencemar. Kelompok bahan pencemar dapat berupa zat padatan, organik, anorganik, cairan berminyak, maupun bahanbahan kimia (Wardhana, 2004).

\section{Kesimpulan}

Komunitas fitoplankton perairan bendungan Sumi meliputi 80 spesies dan 13 kelas. Indeks keanekaragaman spesies fitoplankton lebih besar dari 3 (keragaman kategori tinggi). Kriteria pencemaran air berdasarkan indeks keanekaragaman spesies fitoplankton sebagai indikator biologi (bioindikator), menunjukan kondisi perairan bendungan Sumi tergolong dalam kondisi tidak tercemar.

\section{Ucapan Terima kasih}

Penulis menyampaikan terimakasih kepada berbagai pihak yang telah membantu dalam penelitian ini, terutama kepada Fakultas Keguruan dan Ilmu Pendidikan Universitas Mataram yang telah menyediakan Laboratorium untuk penelitiaan serta Balai Wilayah Sungai Nusa Tenggara 1 yang mengizinkan penelitian di bendungan Sumi.

\section{References}

Apridayanti, E. (2008). Evaluasi Pengelolaan Lingkungan Perairan Waduk Lahor Kabupaten Malang Jawa Timur. Tesis Ilmu Lingkungan Universitas Diponegoro. Semarang

Ariana, D., Samiaji, J., \& Nasution, S. (2014). Komposisi jenis dan kelimpahan fitoplankton perairan laut Riau. Doctoral Dissertation. Riau University, Riau.

Aryawati, R., Ulqodry, T. Z., \& Surbakti, H. (2021). Fitoplankton Sebagai Bioindikator Pencemaran Organik Di Perairan Sungai Musi Bagian Hilir Sumatra Selatan. Jurnal Ilmu dan Teknologi Kelautan Tropis, 13(1), 163-171.

Barus, T. A. (2002). Limnologi. Makassar: Nas Media Pustaka. 
Barus, T. A. (2004). Faktor-faktor Lingkungan Abiotik dan Keanekaragaman Plankton Sebagai Indikator Kualitas Perairan Danau Toba. Manusia dan Lingkungan. 11(2): 64-72.

Bellinger, E. G. \& Sigee, D. C. (2010). Freshwater Algae Identification and Use as Bioindicators. Chichester: John Wiley and Sons, Ltd.

Direktorat Jenderal Sumber Daya Air Nusa Tenggara Barat. (2021). Website https://sda.pu.go.id/balai/bwsnt1/post/58/ profil-bendungan-sumi (Diakses 6 Desember 2021).

Effendi, H. (2003). Telah Kualitas Air Bagi Pengelolaan Sumber daya dan Lingkungan Perairan. Yogyakarta: Kanisius.

Heriyanto, N. M. (2016). Keragaman plankton dan kualitas perairan di hutan mangrove. Buletin Plasma Nutfah, 18(1), $38-44$.

Husamah \& Rahardjanto, A. (2019). Bioindikator (Teori dan Aplikasi Dalam Biomonitoring. Malang: Universitas Muhammadya Malang.

Indriyanto. (2012). Ekologi Hutan. Jakarta: Bumi Aksara.

Japa, L. \& Khairuddin. (2014). Komunitas Fitoplankton Perairan Pantai Utara, Timur, Dan Selatan Pulau Lombok. Jurnal Biologi Tropis, 14(2), 100-107.

Kementerian pekerjaan umum dan perumahan rakyat. (2021). Website https://data.pu.go.id/dataset/bendungan (Diakses 6 Desember 2021).

Khairuddin, Yamin, M., \& Syukur, A. (2016). Analisis Kualitas Air Kali Ancar dengan Menggunakan

Bioindikator Makroinvertebrata. Jurnal Biologi Tropis, Volume 16(2), 10 -22.

Khalis, T. A. D. (2021). Kelimpahan Fitoplankton Sebagai Bioindikator Pada Air Permukaan Danau Buatan Selais Kampus Universitas Riau. Skripsi. Fakultas Matematika dan Ilmu Pengetahuan Alam, Universitas Riau, Riau.

Komalasari, E., Khairuddin, \& Japa, L. (2020). The Diatom Community in Maluk Coastal Water in West Sumbawa. 1st Annual Conference on Education and Social Sciences (ACCESS 2019). Atlantis Press. 465: 259-262.
McLaughlin, R. B. (2012). An Introduction to the Microscopical Study of Diatoms. United States of America.

Michael, P. (1994). Metode Ekologi untuk Penyelidikan Lapangan dan Laboratorium. Jakarta: Universitas Indonesia Press.

Odum, E.P. (1998). Dasar-dasar Ekologi (Fundamentals of Ecology). Diterjemahkan oleh Tj. Samingan. Gajah Mada University Press.

Peraturan Menteri Kesehatan Republik Indonesia Nomor 492 Tahun 2010 Tentang Persyaratan Kualitas Air Minum.

Praseno, D.P \& Sugestiningsih. (2000). Retaid di Perairan Indonesia. Jakarta: P3O-LIPI.

Prilestari, N. K., Aryawati, R., \& Ningsih, E. N. (2019). Hubungan Struktur Komunitas Fitoplankton Dengan Kualitas Perairan Di Perairan Pantai Timur Kabupaten Bangka Tengah Provinsi Bangka Belitung. Doctoral Dissertation. Sriwijaya University, Palembang.

Rahayu, S. (2007). Kelimpahan dan Keanekaragaman Jenis Plankton di Perairan Keramba jaring apung waduk Cirata. Ekologya, 7(2):9-18.

Rumanti, M., Rudiyanti, S., \& Nitisupardjo, M. (2014). Hubungan antara kandungan nitrat dan fosfat dengan kelimpahan fitoplankton di Sungai Bremi Kabupaten Pekalongan. Diponegoro Journal of Maquares, 3(1):168-176.

Sahoo, D., \& Seckbach, J. (2016). The Algae World. New York: Springer Science Business Media Dordrecht.

Suthers, I. M., \& Rissik, D. (2009). Plankton. Austalia: CSIRO Publishing.

Suryanto, A. M., \& Umi, H. (2009). Pendugaan status trofik dengan pendekatan kelimpahan fitoplankton dan zooplankton di waduk sengguruh, Karangkates, Lahor, Wlingi Raya dan Wonorejo Jawa Timur. Jurnal Ilmiah Perikanan dan Kelautan, $1(1): 7-13$.

Taufik, I. (2011). Pencemaran pestisida pada perairan perikanan di Sukabumi-Jawa Barat. Media Akuakultur, 6(1):69-75.

Vuuren, S. J. v., Taylor. J., Ginkel. C. v., \& Gerber A. (2006). Easy Identification of the Most Common Freshwater Algae. South Africa: School of Environmental Sciences and Development.

Wardhana, Wisnu. (2004). Dampak Pencemaran Lingkungan. Yogyakarta: Penerbit ANDI. 
Wehr, J. D \& Sheath, R. G. (2003). Freshwater Algae of North America Ecology and Classification. California: Academic Press.

Zohri, L. H. N., Al Idrus, A., \& Japa, L. (2020). Phytoplankton Diversity as Bioindicator of Pandanduri Dam Waters, East Lombok Regency. Jurnal Biologi Tropis, 20(3):355-362.

Zulfiah, N \& Aisyah, A. (2016). Status Trofik Perairan Rawa Pening Ditinjau dari Kandungan Unsur Hara (NO3 danPO4) serta Klorofil-a. Bawal Widya Riset Perikanan Tangkap, 5(3):189-199. 